Received 05.07.2017 Reviewed 09.07.2017 Accepted 12.07.2017

A - study design

B - data collection

C - statistical analysis

D - data interpretation

$\mathbf{E}$ - manuscript preparation

F - literature search

\section{Efficiency of organic substance removal in a hybrid sand filter with horizontal flow}

\author{
Krzysztof JÓŹWIAKOWSKI ${ }^{\mathrm{ABCDEF} \otimes}$
}

University of Life Sciences in Lublin, Faculty of Production Engineering, Department of Environmental Engineering and Geodesy, ul. Leszczyńskiego 7, 20-069, Lublin, Poland; e-mail: krzysztof.jozwiakowski@up.lublin.pl

For citation: Jóźwiakowski K. 2017. Efficiency of organic substance removal in a hybrid sand filter with horizontal flow. Journal of Water and Land Development. No. 35 p. 95-100. DOI: 10.1515/jwld-2017-0072.

\begin{abstract}
The paper presents the results of the research about the efficiency of organic substance removal in a hybrid sand filter. The investigations were carried out on a model wastewater treatment plant consisting of a preliminary sedimentation tank and two sand filter with a horizontal flow of wastewater (aerobic and anaerobic beds). The efficiency of $\mathrm{BOD}_{5}$ and COD removal was analysed for different wastewater hydraulic load levels: $0.72 ; 1.08$; $1.44 \mathrm{dm}^{3} \cdot \mathrm{d}^{-1}$. The best efficiency of $\mathrm{BOD}_{5}$ and COD removal was obtained when the hydraulic load level was $1.08 \mathrm{dm}^{3} \cdot \mathrm{d}^{-1}$, respectively 83.8 and $72.3 \%$. The average values of $\mathrm{BOD}_{5}$ and COD in the treated wastewater were significantly higher than the values deemed acceptable by relevant regulations in Poland. Based on the studies in the analyzed case, it was found that, sand filters with horizontal flow, do not guarantee high effluent treatment effect of typical household wastewater. In order to obtain a better efficiency of organic substance removal in a hybrid sand filter wastewater need to be oxygenate before being carried to these systems.
\end{abstract}

Key words: $B O D_{5}, C O D$, efficiency, horizontal flow, sand filter, wastewater treatment

\section{INTRODUCTION}

In recent years in rural areas in Poland, there can be seen an intensive development of water and waste water management [BUGAJSKI et al. 2017; JÓŹWIAKOWSKI 2016; JÓŹWIAKOWSKI, PYTKA 2010; JÓŹWIAKOWSKI et al. 2012; PAWEŁEK 2016], which is connected with the implementation of the requirements from Council Directive 91/271/EC signed on $21^{\text {st }}$ May 1991 concerning the issue of urban wastewater treatment. The realization of these requirements includes investment activities concerning building, expansion and modernisation of sewerage systems as well as collective and domestic wastewater treatment plants.

According to the Central Statistical Office of Poland (Pol. Główny Urząd Statystyczny - GUS) data [GUS 2016] in 2015 94.6\% of cities inhabitants used collective wastewater treatment plants, whereas in the country there was the amount of only $39.6 \%$. Such a disproportion is connected with a huge dispersion of houses on the rural areas, which is why it would be economically ungrounded to build collective wastewater sewerage systems and sewage treatment plants. In such areas wastewater is generally hold in septic tanks known as cesspits and in 2015 there were over 2 million of them [GUS 2016]. For over 20 years there has been observed a systematic fall in the amount of septic tanks for the benefit of the number of domestic wastewater treatment plants. In 2015 in Poland there were 202783 such objects registered and every year this quantity increases by about 22000 pieces. So far, the biggest number of domestic wastewater treatment plants has been constructed in such voivodeships: Masovian - 27 056, Kuyavian-Pomeranian - 24162 and Lublin - 22 329. Nonetheless, the least of such objects have been built in these voivodeships: Opole - 4131 and Podkarpackie - 2460 [GUS 2016; SIWIEC 2017]. Among the technological solutions used in domestic sewage treatment plants are: 1 - systems with spreading drainage, 2 - sand filters, 3 - treatment plants with active sediment, 4 - treatment plants with biological bed, 5 - hybrid systems 
(active sludge + biological bed), 6 - constructed wetland systems (one-stage and hybrid) [JAWECKI et al. 2017; JÓźWIAKOWSKI et al. 2015]. The technological solution chosen to be used in domestic sewage treatment plants, which are planned to be built in the area of the community, must be in accordance with sustainable development [JÓźWIAKOWSKI et al. 2015; Mucha, Mikosz 2009]. However, the fact that in Poland for many years so far the most commonly (71\%) used ones are systems with the spreading drainage [JÓźWIAKOWSKI et al. 2012]. According to many authors these systems should not be installed as they enable only mechanical sewage treatment and they contribute to the degradation of the surface water and groundwater quality [JUCHERSKI, WALCZOWSKI 2001; OBARSKA-PEMPKOWIAK 2005; ORLIK, JÓŹWIAKOWSKI 2003; PALUCH, PUlikOWSKI 2004]. An increase in the amount of domestic wastewater treatment plants used in Poland indicates that there is a strong need to control them in the field of the efficiency and their functional reliability [JÓźWIAKOWSKI et al. 2017a]. Special attention must be given to the research connected with the exploitation of spreading drainage systems and sand filters, which are the most often used in rural areas in Poland [CHMIELOWSKI, ŚLI-ZOWSKI 2008; JÓŹWIAKOWSKI et al. 2012].

The aim of the work is to determinant of the removal effectiveness of an organic substance describe by the two indicators: $\mathrm{BOD}_{5}$ and $\mathrm{COD}$ in the hybrid systems. This system is consist of: settling tank and two sand filters with horizontal sewage flow. Moreover the idea of research was to show, if this type of systems can be uses in the field conditions to protect quality of surface and underground water.

\section{CHARACTERISTICS OF THE EXPERIMENTAL OBJECT}

The research was carried out on the experimental object constructed in the laboratory conditions. The research installation consisted of two main pieces:

1) controlling, measuring and checking apparatus;

2) model wastewater treatment plant (Fig. 1).

The controlling, measuring and checking apparatus consisted of: a special driver of the chemical process SPC 10, 4 peristaltic pumps from an American company Gorman-Rupp Industries, a temporal flow regulator, oxygen probe Oxyferm 120 and pH electrode Easyferm 120 from an American company Hamilton, temperature detector PT-100 from a Polish company Elmetron and a computer.

The model wastewater treatment plant consisted of three parallel wastewater treatment systems containing a dual-chamber preliminary sedimentation tank and two further sand beds with a horizontal sewage flow: aerobic and anaerobic ones (Fig. 1). The area of the sand beds (aerobic and anaerobic) was $0.0916 \mathrm{~m}^{2}$ and their depth was $0.07 \mathrm{~m}$. The canal's
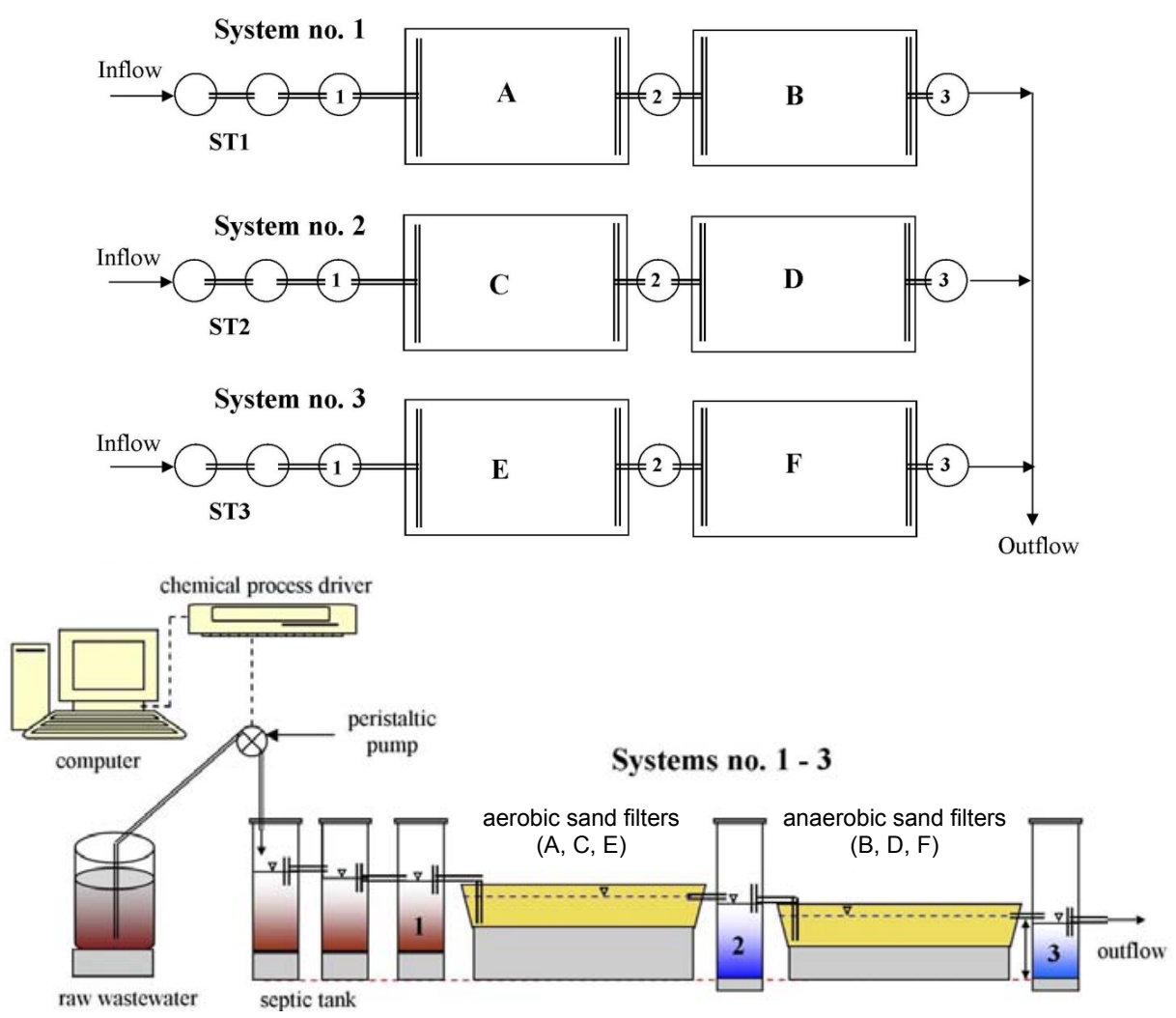

Fig. 1. A schematic diagram of the wastewater treatment plant model (WWTP); ST1, ST2, ST3 = two-chamber septic tanks; 1, 2, 3 = sampling points; A, C, E = sand filters with horizontal flow (with oxygen); B, D, F = sand filters with horizontal flow (without oxygen); source: own elaboration 
gradient in the beds was $1 \%$ towards the sewage outflow. The spreading drainage - inflow and the collecting one - outflow were constructed from pipes with a diameter of $\phi=0.01 \mathrm{~m}$ with special cuts. In order to fill the beds with a horizontal flow (A, B, C, D, E, F) mean sand was used $(\phi=1-2 \mathrm{~mm})$. The main parameters of the model wastewater treatment plant have been shown in the Table 1.

Table 1. Basic technological parameters of the model wastewater treatment plant

\begin{tabular}{|l|c|c|c|}
\hline \multicolumn{1}{|c|}{ Parameter } & $\begin{array}{c}\text { Measurement } \\
\text { unit }\end{array}$ & $\begin{array}{c}\text { Primary } \\
\text { sedimentation } \\
\text { tank chambers } \\
\text { I and II }\end{array}$ & $\begin{array}{c}\text { Aerobic } \\
\text { and anaerobic } \\
\text { sand filters }\end{array}$ \\
\hline Lenght $L$ & $\mathrm{~m}$ & - & 0.390 \\
\hline Width $W$ & $\mathrm{~m}$ & - & 0.235 \\
\hline Diameter $D$ & $\mathrm{~m}$ & 0.075 & - \\
\hline Total depth $H$ & $\mathrm{~m}$ & 0.240 & 0.060 \\
\hline $\begin{array}{l}\text { Height of wastewater } \\
\text { level } h\end{array}$ & $\mathrm{~m}$ & 0.160 & 0.050 \\
\hline Area $A$ & $\mathrm{~m}^{2}$ & - & 0.092 \\
\hline Total volume $V$ & $\mathrm{dm}^{3}$ & 1.059 & 5.499 \\
\hline Acive volume $V_{c z}$ & $\mathrm{dm}^{3}$ & 0.707 & 4.582 \\
\hline
\end{tabular}

Source: own elaboration.

\section{METHODS OF RESEARCH}

The research concerning the efficiency of organic substance removal, shown with such indicators as $\mathrm{BOD}_{5}$ and $\mathrm{COD}$, was being carried out in the model wastewater treatment plant for 8 weeks. Domestic waste water used in the research was brought once a week from the preliminary sedimentation tank of the domestic wastewater treatment plant functioning in real conditions. The tests were conducted with such sewage flow levels: $0.72 ; 1.08$ and $1.44 \mathrm{dm}^{3} \cdot \mathrm{d}^{-1}$, which suited to the sewage inflow to three analysed systems in a quantity of: $0.5 ; 0.75$ and $1 \mathrm{ml} \cdot \mathrm{min}^{-1}$. The hydraulic sewage load of the beds'(aerobic and anaerobic) area ranged from 0.008 to $0.016 \mathrm{~m}^{3} \cdot \mathrm{m}^{-2} \cdot \mathrm{d}^{-1}$, while the waste water retention time ranged from $11 \mathrm{~h}$ $47 \mathrm{~min}$ to $23 \mathrm{~h} 32 \mathrm{~min}$ - in the preliminary sedimentation tanks and from $30 \mathrm{~h} 33 \mathrm{~min}$ to $61 \mathrm{~h} 06 \mathrm{~min}$ - in the aerobic and anaerobic beds.

In order to show the effects of organic substance removal in various levels of hydraulic load of $\mathrm{BOD}_{5}$ and COD were measured: 1 - in the wastewater after it's mechanical purification, 2 - in the sewage outflowing from the aerobic bed and 3 - in the sewage outflowing from the anaerobic bed. During the research there were taken altogether 6 series of the analysis -2 series for each hydraulic load level. The analysis of the size of the measured indicators in the sewage were made in accordance with the commonly used methods [APHA 2002; 2005]. The calculation of the effects of the decrease of $\mathrm{BOD}_{5}$ and COD at each treatment stage were based on the change in the amount of analysed indicators in the inflow and outflow waste water in the particular element of the treatment plant and this formula was used:

$$
\eta=\left(-\frac{C_{d}-C_{o}}{C_{d}}\right) 100 \%
$$

where: $C_{o}=$ the concentration of the pollutants in the sewage outflowing from the treatment plant; $C_{d}=$ the concentration of the pollutants in the sewage inflowing to the treatment plant.

\section{RESULTS OF THE RESEARCH AND THE DISCUSSION}

In the Table 2 there has been shown the composition of the sewage treated in the model wastewater treatment plant with different levels of hydraulic load.

During the research the temperature of wastewater inflowing to the model treatment plant ranged from 14.9 to $18.8^{\circ} \mathrm{C}$. However, the $\mathrm{pH}$ value was about 7.01-7.46, which shows it's soft alkaline character. The tests have revealed a small amount of oxygen dissolved in the waste water after mechanical treatment: $0.19-0.56 \mathrm{mg} \mathrm{O} \cdot \mathrm{dm}^{-3}$. From the literature we know that the concentration of oxygen dissolved at this level can restrict the effective waste water treatment. The minimal concentration of oxygen should range from 1 to $2 \mathrm{mg} \mathrm{O}{ }_{2} \cdot \mathrm{dm}^{-3}$ in order to enable an effective process of pollutants oxidation [BERNACKA et al. 1995].

Sewage delivered to the tested purification systems were characterised by different amounts of $\mathrm{BOD}_{5}$ and $\mathrm{COD}$. The value of $\mathrm{BOD}_{5}$ ranged from 213 to $255 \mathrm{mg} \mathrm{O} \mathrm{O}_{2} \cdot \mathrm{dm}^{-3}$ and the value of COD: from 340 to $530 \mathrm{mg} \mathrm{O} \cdot \mathrm{dm}^{-3}$. The composition of the sewage delivered to the tested object was similar to this which is common in the typical domestic wastewater discharged from the households [BERGIER, WŁODYKA-

Table 2. The parameters of sewage treated in the model sewage treatment plant with different hydraulic load levels

\begin{tabular}{|c|c|c|c|c|c|c|c|c|c|c|}
\hline \multirow{3}{*}{ Parameter } & \multirow{3}{*}{$\begin{array}{l}\text { Measurement } \\
\text { unit }\end{array}$} & \multicolumn{9}{|c|}{ Hydraulic load $Q_{d}$} \\
\hline & & \multicolumn{3}{|c|}{$Q_{1}=1.44 \mathrm{dm}^{3} \cdot \mathrm{d}^{-1}$} & \multicolumn{3}{|c|}{$Q_{2}=1.08 \mathrm{dm}^{3} \cdot \mathrm{d}^{-1}$} & \multicolumn{3}{|c|}{$Q_{3}=0.72 \mathrm{dm}^{3} \cdot \mathrm{d}^{-1}$} \\
\hline & & 1 & 2 & 3 & 1 & 2 & 3 & 1 & 2 & 3 \\
\hline Temperature of wastewater & ${ }^{\circ} \mathrm{C}$ & 16.90 & 16.50 & 17.00 & 14.90 & 14.60 & 14.50 & 18.80 & 18.60 & 18.60 \\
\hline $\mathrm{pH}$ & - & 7.46 & 7.84 & 8.21 & 7.38 & 7.94 & 8.06 & 7.01 & 7.94 & 8.17 \\
\hline $\mathrm{O}_{2}$ & $\mathrm{mg} \mathrm{O}_{2} \cdot \mathrm{dm}^{-3}$ & 0.42 & 0.98 & 1.39 & 0.56 & 1.15 & 2.00 & 0.19 & 0.57 & 3.12 \\
\hline $\mathrm{BOD}_{5}$ & $\mathrm{mg} \mathrm{O}_{2} \cdot \mathrm{dm}^{-3}$ & 255 & 173 & 145 & 253 & 54 & 41 & 213 & 117 & 83 \\
\hline COD & $\mathrm{mg} \mathrm{O}_{2} \cdot \mathrm{dm}^{-3}$ & 530 & 230 & 210 & 470 & 140 & 130 & 340 & 230 & 100 \\
\hline
\end{tabular}

Explanations: 1 = sewage after mechanical treatment, 2 = sewage outflowing from the aerobic beds, $3=$ sewage outflowing from the anaerobic beds; $\mathrm{BOD}_{5}=5$ day biochemical oxygen demand, $\mathrm{COD}=$ chemical oxygen demand.

Source: own study. 
-Bergier 2012; Bugajski, Bergel 2008; ChMieLOWSKI et al. 2016; HEIDRICH, KOZAK 2009; KACZOR 2009].

On the ground of the level of an average daily sewage inflow to the model treatment plant and the values of $\mathrm{BOD}_{5}$ and COD in the waste water there had been calculated the pollutant load in the tested system (Fig. 2).

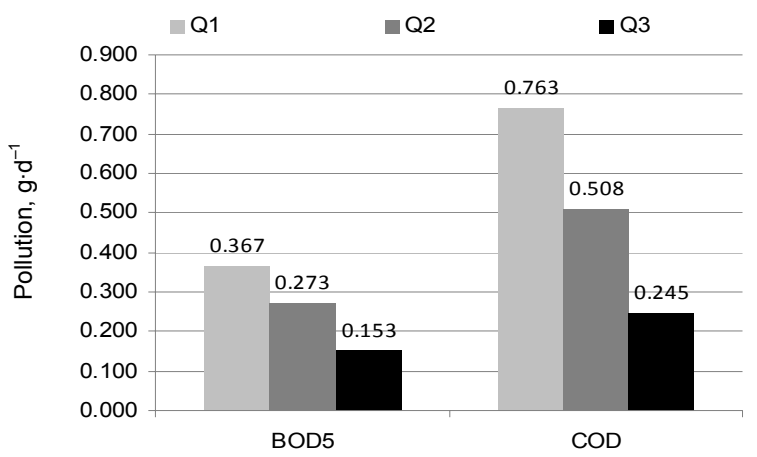

Fig. 2. The pollutant load in the sewage inflowing

to the model treatment plant; $Q_{1}=1.44 \mathrm{dm}^{3} \cdot \mathrm{d}^{-1}$, $Q_{2}=1.08 \mathrm{dm}^{3} \cdot \mathrm{d}^{-1}, Q_{3}=0.72 \mathrm{dm}^{3} \cdot \mathrm{d}^{-1}$; source: own study

According to the data shown at the Figure 2 it can be seen that the organic pollutant load inflowing to the tested object depended especially on the amount of the inflowing waste water. It has been observed that the biggest pollutant loads were brought to the model treatment plant by the highest hydraulic load $\left(Q_{1}=1.44 \mathrm{dm}^{3} \cdot \mathrm{d}^{-1}\right)$ and alongside with its decrease (to $Q_{3}=0.72 \mathrm{dm}^{3} \cdot \mathrm{d}^{-1}$ ), they were significantly diminishing - even by over $50 \%$ (Fig. 2). It has been stated that the organic pollutant load level of $1 \mathrm{dm}^{3}$ of the sewage inflowing to the analysed object decreased from $0.367 \mathrm{~g} \cdot \mathrm{d}^{-1}$ (by $Q_{1}$ ) to $0.153 \mathrm{~g} \cdot \mathrm{d}^{-1}$ (by $Q_{3}$ ) - for $\mathrm{BOD}_{5}$ and from $0.763 \mathrm{~g} \cdot \mathrm{d}^{-1}$ (by $Q_{1}$ ) to $0.245 \mathrm{~g} \cdot \mathrm{d}^{-1}$ (by $Q_{3}$ ) - for COD.

The values of the indicators tested in the sewage out flowing in the particular stages of the purification were much smaller than in the inflow wastewater. The effects of the organic pollutants $\left(\mathrm{BOD}_{5}\right.$ and $\left.\mathrm{COD}\right)$ removal in the analysed treatment plant were various at different hydraulic and pollutant loads which has been indicated in the research results shown in the Figure 3.

The research has shown that the best effects of the organic substance removal, expressed by such indicators as $\mathrm{BOD}_{5}(83.8 \%)$ and $\mathrm{COD}(72.3 \%)$, were in the whole wastewater treatment plant achieved by the $Q_{2}=1.08 \mathrm{dm}^{3} \cdot \mathrm{d}^{-1}$ hydraulic load. On the other hand, the least effects of $\mathrm{BOD}_{5}$ and COD decrease were obtained by the biggest hydraulic load $Q_{1}$ (Fig. 3 ). To compare, according to the research carried by CHMIELOWSKI et al. [2011] the effects of $\mathrm{BOD}_{5}$ and COD elimination in the sand filter with a horizontal flow are respectively: $83-90 \%$. It has been observed that the best effects of $\mathrm{BOD}_{5}$ and COD removal in the tested system were achieved the most often in the I aerobic bed-respectively: $32.0-78.9 \%$ and $32.4-$ a)

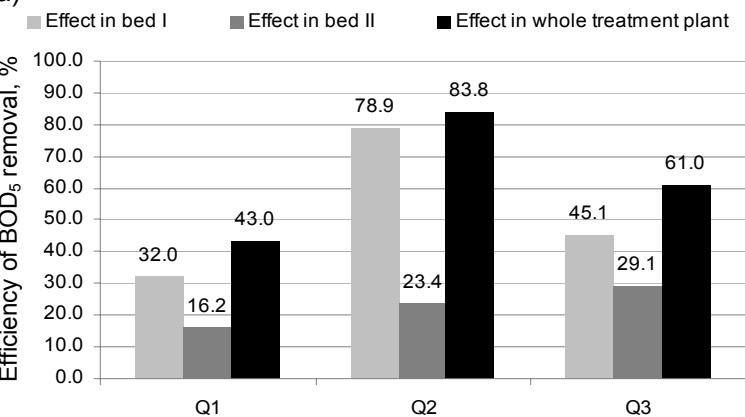

b)

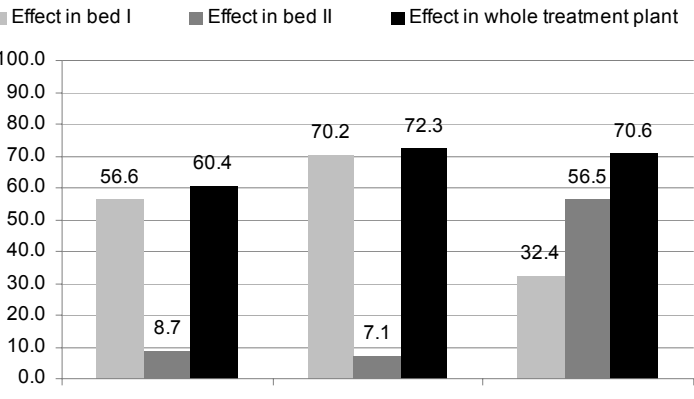

Q1

Q2

Q3

Fig. 3. The effects of the organic pollutants removal at particular stages of wastewater treatment by different levels of hydraulic load; $Q_{1}, Q_{2}, Q_{3}$ as in Fig. 2; source: own study

$70.7 \%$ but much worse in the II anaerobic bed - respectively: $16.2-29.1 \%$ and $7.1-32.4 \%$ (Fig. 3).

The results of the research shown in the Table 2 indicate that the COD values in the outflow, by the hydraulic load $Q_{2}$ and $Q_{3}$, did not exceed permitted levels $\left(150 \mathrm{mg} \mathrm{O}_{2} \cdot \mathrm{dm}^{-3}\right)$ determined in the Regulation of The Minister of The Environment [Rozporządzenie MŚ... 2014]. However, by the hydraulic load $Q_{1}$ the permitted value of COD was exceeded. For $\mathrm{BOD}_{5}$ the permitted level $\left(40 \mathrm{mg} \mathrm{O}_{2} \cdot \mathrm{dm}^{-3}\right)$ determined in the regulation [Rozporządzenie MŚ... 2014] in the sewage out flowing from the tested sand filters was exceeded by all three levels of the hydraulic load (Tab. 2).

The research revealed that the sand filters working in laboratory conditions with specific hydraulic and pollutant load do not provide suitable efficiency of the elimination of organic substance expressed by such indicators as $\mathrm{BOD}_{5}$ and COD. According to the research of ORLIK and JÓźWIAKOWSKI [2003] the efficiency of organic substance removal in the systems with spreading drainage (with a vertical flow) used in real conditions is also small. These authors proved that the effects of $\mathrm{BOD}_{5}$ and COD decrease in such objects were respectively: $29.4-38.2 \%$ and $21.2-$ $30.4 \%$, so they were much lower than these ones obtained in the model installation.

The received results show that sand filters with a horizontal flow should not be used to treat domestic wastewater, as well as domestic wastewater treatment plants using only systems with spreading drainage, which are not able to purify sewage [ORLIK, JóźWIAKOWSKI 2003]. The main reason of a small efficiency of organic substance removal in such systems is the 
lack of oxygen in the treated sewage and that is why the processes of biological removal of organic substances and nitrogen compounds do not proceed appropriately. The effects of the decrease of $\mathrm{BOD}_{5}$ and nitrogen compounds in such objects can be improved for instance by using hydrogen peroxide $\left(\mathrm{H}_{2} \mathrm{O}_{2}\right)$. The research done by JÓŹWIAKOWSKI et al. [2017b] has shown that by using this unconventional method of sewage oxygenation the effects of $\mathrm{BOD}_{5}$ decrease in a one-stage sand filter with a horizontal flow were maximally $94.3 \%$, whereas the average value of $\mathrm{BOD}_{5}$ in the purified wastewater was $4.4 \mathrm{mg} \mathrm{O} \mathrm{O}_{2} \cdot \mathrm{dm}^{-3}$.

\section{CONCLUSIONS}

1. There has been proved that the tested hybrid sand filters are not able to prove an efficient elimination of organic substance expressed by such indicators as: $\mathrm{BOD}_{5}$ and $\mathrm{COD}$. The best effects of the reduction of these parameters in analysed systems obtained by the hydraulic load at the level of $Q_{2}=1.08 \mathrm{dm}^{3} \cdot \mathrm{d}^{-1}$ were respectively: 83.8 and $72.3 \%$. The $\mathrm{BOD}_{5}$ and COD removal by the $Q_{1}$ hydraulic load were respectively $40.3 \%$ and $60.4 \%$ and by $Q_{3}$ these values were respectively $61.0 \%$ and $70.6 \%$.

2. The biggest effects of $\mathrm{BOD}_{5}$ and COD reduction were obtained mainly in the I aerobic bed and much smaller ones in the II anaerobic bed.

3. The average values of $\mathrm{BOD}_{5}$ and $\mathrm{COD}$ in the treated wastewater usually were significantly higher than the values deemed acceptable by relevant regulations in Poland.

4. The results achieved in this research show that the sand filters with the horizontal flow should not be used to treat domestic wastewater. In order to obtain better effects of organic substance removal in sand filters there is a strong need to oxygenate the sewage before delivering them to these systems.

\section{Acknowledgement}

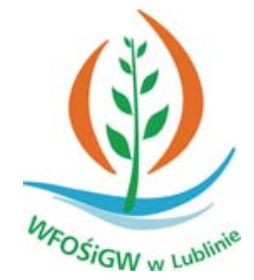

Dofinansowano ze środków Wojewódzkiego Funduszu Ochrony Środowiska i Gospodarki Wodnej w Lublinie Cofinanced by Voivodeship Fund for Environmental Protection and Water Management in Lublin

\section{REFERENCES}

APHA 1992. Standard methods for examination of water and wastewater. $18^{\text {th }}$ ed. Washington. American Public Health Association pp. 1100.

APHA 2005. Standard methods for examination of water and wastewater. $21^{\text {st }}$ ed. Washington. American Public Health Association pp. 1200.

BERgier T., WŁOdYKA-Bergier A. 2012. Efektywność oczyszczania ścieków w przydomowej hybrydowej oczyszczalni hydrofitowo-biologicznej [The efficiency of wastewater treatment with the household hybrid (biological-constructed wetland) wastewater treatment plant]. Woda-Środowisko-Obszary Wiejskie. T. 12. Z. 1 p. $25-36$.

Bernacka J., KuRBiel J., PAwŁowsKa L. 1995. Usuwanie związków biogennych ze ścieków miejskich [Removal of biogenic compounds from minicipal wastewater]. Warszawa. IOŚ. ISBN 83-85805-19-2 pp. 92.

BugAJSKi P., BeRgel T. 2008. Wielkości wybranych stężeń zanieczyszczeń $\mathrm{w}$ ściekach bytowych odpływających $\mathrm{z}$ terenów wiejskich [Size of selected pollutant concentrations in domestic wastewater from rural areas]. Gaz, Woda i Technika Sanitarna. Nr 9 p. 28-29.

Bugajski P., Gajewska M., Jóźwiakowski K., Siwiec T. 2017. Rozwiązania technologiczne stosowane w gospodarce wodno-ściekowej na terenach wiejskich [Technological solutions used in water and sewage management in rural areas]. W: Ochrona i kształtowanie zasobów wodnych na terenach wiejskich. [Protection and development of water resources in rural areas]. Ed. K. Jóźwiakowski, W. Siuda. Warszawa-Katowice. Fundacja na rzecz Rozwoju Polskiego Rolnictwa, Wydaw. S-PRINT 2 p. 55-70.

Chmielowski K., Bugajski P., KaCzor G. 2016. Comparative analysis of the quality of sewage discharged from selected agglomeration sewerage systems. Journal of Water and Land Development. No. 30 p. 35-42. DOI 10.1515/jwld-2016-0019.

ChMielowsKi K., ŚLIzowsKi R. 2008. Wpływ uziarnienia złoża filtrów pisakowych o przepływie pionowym na jakość filtratu [Effect of grain-size distribution of Sand on the filtrate quality in vertical-flow filters]. Przemysł Chemiczny. T. 87. Nr 5 p. 432-434.

Chmielowski K., Ślizowski R., PęGiel K. 2011. Ocena działania przydomowej oczyszczalni ścieków z filtrem piaskowym o przepływie poziomym [Evaluation of performance household sewage treatment plant based on a horizontal flow sand filter]. Infrastruktura i Ekologia Terenów Wiejskich. Z. 2 p. 215-223.

Council Directive 91/271/EC of May 21, 1991 concerning urban waste water treatment. Official Journal of the European Communities p. 135/40-135/52.

GUS 2016. Infrastruktura komunalna w 2015 r. [Municipal infrastructure in 2015]. Warszawa pp. 36.

HEIDRICH Z., KoZAK T. 2009. Jednostkowe ładunki zanieczyszczeń charakteryzujące ścieki miejskie [Unitary pollution chargé typical of communal sewage]. Gaz, Woda i Technika Sanitarna. Nr 12 p. 20-22.

Jawecki B., Pawęska K., Sobota M. 2017. Operating household wastewater treatment plants in the light of binding quality standards for wastewater discharged to water bodies or to soil. Journal of Water and Land Development. No. 32 p. 31-39. DOI 10.1515/jwld-20170004.

JÓŹWIAKOWSKI K. 2016. Innowacyjne technologie w gospodarce wodno-ściekowej [Innovative technologies in water and sewage management]. Wiadomości Melioracyjne i Łąkarskie. Nr 4 p. 170-180.

JóźWiakowski K., Bugajski B., Mucha Z., Wójcik W., JuCherski A., NASTAwny M., SiwieC T., MaZur A., OBRoŚLAK R., GAJEWSKA M. 2017a. Reliability of pollutions removal processes during long-term operation of one-stage constructed wetland with horizontal flow [online]. Separation and Purification Technology. Vol. 187 p. 60-66.

JóźWiaKowsKi K., MARZeC M., FiedUREK J., KAMIŃSKa A., Gajewska M., WojciechowsKa E., Shubiao W., DaCH J., MarczuK A., KowalczYK-JuŚKo A. 2017b. Application of $\mathrm{H}_{2} \mathrm{O}_{2}$ to optimize of ammonium removal from 
domestic wastewater. Separation and Purification Technology. Vol. 173 p. 357-363.

Jóźwiakowski K., Mucha Z., Generowicz A., Baran S., BIELIŃSKA J., WÓJCIK W. 2015. The use of multi-criteria analysis for selection of technology for a household WWTP compatible with sustainable development. Archives of Environmental Protection. Vol. 3 p. 76-82.

JóźWIAKOwski K., PYTKA A. 2010. Rozwój gospodarki wodno-ściekowej na terenach wiejskich w Polsce w latach 1990-2008. Gospodarka odpadami komunalnymi. [Development of water and sewage management in rural areas in Poland in 1990-2008]. Monografia Komitetu Chemii Analitycznej PAN. T. VI p. 31-39.

JóźWiakowski K., PytKa A. Marzec M., GziŃSKa M., DĄBeK J., GŁAz B., SŁawiŃSKa A. 2012. Rozwój infrastruktury wodno-ściekowej w województwie lubelskim w latach 2000-2011 [Development of water and wastewater infrastructure in Lublin Province in 2000-2011]. Infrastruktura i Ekologia Terenów Wiejskich. Z. 3/I p. 73-86.

JUCHERSKi A., WALCzowsKi A. 2001. Drenaże rozsączające. Oczyszczanie czy odprowadzanie nieoczyszczonych ścieków do gleby [Drainage systems. Purification or draining of untreated sewage into the soil]. Wiadomości Melioracyjne i Łąkarskie. Nr 3 p. 131-132.

KACZOR G. 2009. Stężenia zanieczyszczeń w ściekach odprowadzanych $\mathrm{z}$ wiejskich systemów kanalizacyjnych województwa małopolskiego [Concentrations of the pollutants in the sewage drained from the rural sewerage systems in lesser Poland voivedeship]. Infrastruktura i Ekologia Terenów Wiejskich. Z. 9 p. 97-104.

Mucha Z., Mikosz J. 2009. Racjonalne stosowanie małych oczyszczalni ścieków z uwzględnieniem kryteriów zrównoważonego rozwoju [Rational application of small wastewater treatment plants according of sustainability criteria]. Czasopismo Techniczne. Środowisko. R. 106. Z. 2-Ś p. 91-100.
OBARSKA-PEMPKOWIAK H. 2005. Oczyszczalnie hydrofitowe w świetle przepisów UE [Constructed wetlands in the light of EU regulations]. Zeszyty Naukowe Wydziału Budownictwa i Inżynierii Środowiska Politechniki Koszalińskiej. Nr 22 p. 77-97.

ORLIK T, JÓźWIAKOWSKI K. 2003. Ocena działania dwóch przydomowych oczyszczalni ścieków typu BATEX $\mathrm{z}$ drenażem rozsączającym [Evaluation of the operation of two BATEX sewage treatment plants with drainage system]. Inżynieria Rolnicza. Nr 3(45 t. 1) p. 109-119.

PaluCh J., PulikowsKi K. 2004. Wybrane problemy związane $\mathrm{z}$ budową zagrodowych oczyszczalni ścieków $\mathrm{z}$ drenażem rozsączającym [Selected problems related to the construction of a household sewage treatment plant with drainage system]. Wiadomości Melioracyjne i Łąkarskie. $\mathrm{Nr} 4$ p. 191-198.

PAWEŁEK J. 2016. Degree of development and functionality of the water supply and sewage systems in rural Poland. Barometr Regionalny. T. 14. Nr 1 p. 141-149.

SiwIEC T. 2017. Stan obecny zaopatrzenia w wodę, odprowadzania ścieków oraz problemy rozwoju gospodarki wodno-ściekowej na terenach wiejskich [Current status of water supply, sewerage and problems of water and sewage management development in rural areas]. W: Ochrona i kształtowanie zasobów wodnych na terenach wiejskich [Protection and development of water resources in rural areas]. Ed. K. Jóźwiakowski, W. Siuda. Warszawa-Katowice. Fundacja na rzecz Rozwoju Polskiego Rolnictwa. Wydaw. S-PRINT 2 p. 29-33.

Rozporządzenie Ministra Środowiska z dnia 18 listopada 2014 r. w sprawie warunków, jakie należy spełnić przy wprowadzaniu ścieków do wód lub do ziemi oraz w sprawie substancji szczególnie szkodliwych dla środowiska wodnego [Regulation of the Minister of the Environment of November 18, 2014 laying down conditions for the introduction of sewage into water bodies or soil and laying down the list of substances particularly harmful to water environments]. Dz.U. 2014 poz. 1800.

\section{Krzysztof JÓŹWIAKOWSKI}

\section{Efekty usuwania substancji organicznej w hybrydowych filtrach piaskowych z przeplywem poziomym}

\section{STRESZCZENIE}

W pracy zaprezentowano wyniki dotyczące efektywności usuwania substancji organicznej w hybrydowych filtrach piaskowych. Badania prowadzono w modelowej oczyszczalni ścieków składającej się z osadnika wstępnego i dwóch filtrów piaskowych z poziomym przepływem. Efektywność zmniejszania $\mathrm{BZT}_{5}$ i ChZT była analizowana w warunkach różnego obciążenia hydraulicznego ściekami: 0,$72 ; 1,08 ; 1,44 \mathrm{dm}^{3} \cdot \mathrm{d}^{-1}$. Najlepsze efekty obniżania $\mathrm{BZT}_{5}$ i ChZT uzyskano w warunkach obciążenia hydraulicznego na poziomie $1,08 \mathrm{dm}^{3} \cdot \mathrm{d}^{-1}$, odpo-

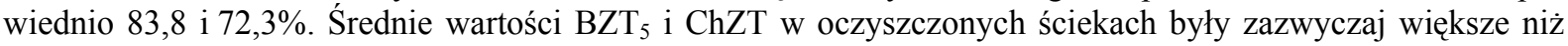
dopuszczalne w odpowiednich przepisach w Polsce. Na podstawie badań w analizowanym przypadku stwierdzono, że filtry piaskowe o przepływie poziomym nie dają gwarancji wysokiej sprawności oczyszczania ścieków bytowych. W celu uzyskania lepszych efektów eliminacji substancji organicznej w filtrach piaskowych konieczne jest napowietrzanie ścieków przed doprowadzeniem ich do tych systemów.

Słowa kluczowe: $B Z T_{5}, C h Z T$, efektywność oczyszczania ścieków, filtr piaskowy, przepływ poziomy 